\title{
Stikstofoksied en die senuweestelsel
}

\author{
H.S. Meij \\ Departement Fisiologie, Fakulteit Geneeskunde, Universiteit van Pretoria, Pretoria, 0002
}

Ontwang 25 Oktober 1995; aanvaar 13 Februstrie 1996

\section{UITTREKSEL}

Betreklik onlangs is ontdek dat stikstofo'sied (NO), 'n giftige gasmolekuul, as 'n sellulêre boodskapper in biologiese stelsels optree. In die menslike liggaam word dit 'sur verskillende seltipes in ' $n$ verskeidenheid van organe geproduseer en vrygestel en het dit ' $n$ fundamentele aandeel in die funksionering van bykans alle liggaamstelsels. Die rol van NO blyk besonder belangrik te wees in die kardiovaskulêre stelsel (veral met betrekking tot vasodilatasie), liggaamsverdediging (vernietiging van patogene), en die senuweestelsel (as neuro-oordragstof en-modulator). In hiendie kort oorsig word aspekte van die vorming en moontlike werking van $N O$ beskryf en die belang van dié gasmolekuul in die senuweestelsel saamgevat. Wat die perifere senuweestelsel betref, word veral aandag gegee aan NO as nie-adrenergiese, nie-cholinergiese (NANC) neuro-oordragstof in outonome senuweeveseleindes. Met betrekking tot die sentrale senuweestelsel, word die modulerende rol van NO op neurale aktiwiteit, veral ten opsigte van die funksies van die eksiterende aminosuuroordragstof glutamaat, uitgelig.

\section{Abstract}

\section{Nitric oxide and the nervous system}

It was discovered fairly recently that nitric oxide (NO), a poisonous gas molecule, can act as a cellular messenger in biological systems. In the human body it is produced and released by several types of cells in a number of different organs, and it apparently plays a fundamental part in the functions of almost all the body systems. Nitric oxide seems to be significantly involved in the cardiovascular system (especially in vasodilation), the defence systems of the body (destruction of pathogens) and in the nervous system as neurotransmitter and -modulator. In this short review aspects regarding the synthesis and possible actions of NO are described, and the importance of this gas molecule in the nervous system is summarised. Regarding the peripheral nervous system, attention is mainly directed towards NO as a nonadrenergic, noncholinergic neurotransmitter at autonomic nerve terminals. As to the central nervous system, the modulatory moles of $N O$ upon neural activity, with special neference to the functions of the excitatory amino acid neurotransmitter glutamate, are highlighted. 


\section{INLEIDING}

Tien jaar gelede sou die idee dat stikstofoksied (NO) as 'n biologiese boodskappermolekuul in die menslike liggaam funksioneer, vergesog gelyk het. In die atmosfeer is NO 'n giftige chemiese gas wat die lug besoedel - onder andere ' $n$ gasproduk van voertuiguitlaatstelsels en sigaretrook. Sedert die ontdekking in 1987 dat NO deur liggaamselle gevorm en vrygestel word, ${ }^{1-4}$ het ' $n$ ontploffing van navorsing oor die sintese en moontlike funksies van NO gevolg. Dit het duidelik geword dat NO verskeie diverse fundamentele funksies in die alledaagse liggaamsprosesse verrig.

Stikstofoksied is die eerste gasmolekuul wat aangetoon is om as biologiese boodskapper in soogdierselle op te tree $^{5}$ en drie jaar gelede is dit deur die tydskrif Science as die "molekuul van die jaar" aangewys. ${ }^{6}$ Uit die literatuur blyk dit tans dat NO in bykans alle liggaamstelsels betrokke is. Die rol van NO kom veral sterk na vore in die kardiovaskulêre stelsel ${ }^{1,2.7 .8}$ waar aktiewe vasodilatasie die bekendste effek is, in liggaamsverdediging ${ }^{9-12}$ waar dit onder andere te doen het met die vemietiging van patogene, en die senuweestelsel waar dit 'n veral 'n neuromodulerende rol speel. ${ }^{13-15}$ Oor- en onderproduksie van NO in die liggaam word selfs al aan spesifieke siekteprosesse gekoppel en navorsing aangaande NO betrek dan ook reeds die ontwikkeling van prosedures en farmaseutiese middels vir die voorkoming en/of behandeling van bepaalde toestande. In hierdie kort oorsig word die literatuur betreffende die biologiese vorming en kenmerke van $\mathrm{NO}$, en enkele aspekte van die belang van die molekuul in die senuweestelsel, saamgevat.

\section{BIOSINTESE EN ALGEMENE WERKINGSWYSE VAN STIKSTOFOKSIED}

Stikstofoksied word gevorm deur bemiddeling van 'n ensiem stikstofoksiedsintetasie (NOS), wat omskakeling van Larginien en molekulêre suurstof na L-sitrullien en NO kataliseer ${ }^{13,16,17}$ (fig. 1).
Die meganismes van stikstofoksiedsintese is nie heeltemal duidelik nie, maar dit sluit elektronoordrag tussen verskeie ko-faktore, insluitende flavien-adenien-dinukleotied, flavienmononukleotied, nikotienamied-adenien-dinukleotiedfosfaat (NADPH), tetrahidrobiopterien en heem, in. ${ }^{17}$

In teenstelling met die klein, eenvoudige stikstofoksiedmolekuul, is stikstofoksiedsintetases (NOS) 'n groot, komplekse proteienmolekule. Drie isovorme van NOS is aangetoon: 'n endoteliale, 'n neuronale en 'n makrofaagtipe. Die gene vir hierdie ensieme is reeds gelokaliseer; onderskeidelik op chromosoom 7 , chromosoom 12 en chromosoom $17 .{ }^{18}$

Die neuronale tipe is aanwesig in sommige sentrale en perifere neurone en die endoteliale tipe in vaskulêre endoteel, bloedplaatjies en in die endo- en miokardium. Hierdie twee isovorme is normale konstituente van die selle waar hulle voorkom en is bekend as konstitutiewe ("constitutive") stikstofoksiedsintetases (cNOS).

Die makrofaagtipe is afwesig in normale selle en word net gevorm na aktivering van sekere selle deur produkte van infeksie, insluitende bakteriěle endo- en eksotoksiene, of inflammatoriese produkte, insluitende die sitokiene, tumornekrosefaktor of interleukien-1. Vorming van hierdie stikstofoksiedsintetase (iNOS) kan in baie seltipes geînduseer word, insluitende makrofage, immuunselle, hepatosiete, vaskulere gladdespier, hartspier en die verteringstelsel. ${ }^{19}$ Produksie van iNOS word deur transkripsie gereguleer. ${ }^{20}$ Eens geïnduseer, gee die ensiem aanleiding tot langdurige vorming van groot hoeveelhede NO vir byvoorbeeld die vernietiging van skadelike mikroörganismes.9-11

Die cNOS sintetiseer klein hoeveelhede NO op aanvraag, wat ' $n$ vinnige, kortstondige effek uitoefen. Wanneer cNOSbevattende selle op gepaste wyse gestimuleer word, verhoog die kalsiumdeurlatendheid van dié selle. Wanneer die intrasellulêre kalsiumvlakke styg, bind $\mathrm{Ca}^{2+}$ aan kalmodulien, en dié kompleks aktiveer die cNOS. Die ensiem kataliseer dan die vorming van klein hoeveelhede NO, totdat die kalsiumvlak terugkeer na normaal. ${ }^{14}$ Die NO diffundeer

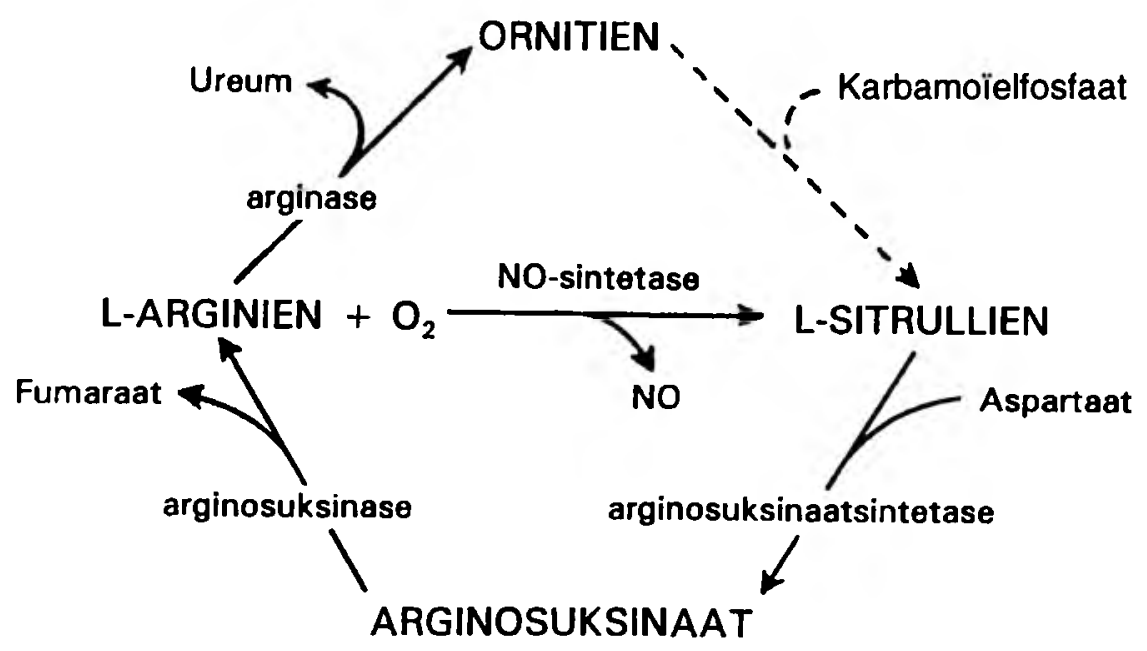

FIGUUR 1: Biosintese van NO vanaf $L$-arginien, en hersirkulering van $L$-sitrullien. Deur hierdie wysiging van die ureumsiklus word die voorloper van NO ( $L$-arginien) geregeneer vanaf die neweproduk ( $L$-sitrullien). ${ }^{13}$ Die ensiem ornitientranskarbamoïelase wat die vorming van sitrullien uit ornitien kataliseer, is nie in die brein aanwesig nie. 
vinnig uit die sel en in naasliggende selle in, waar dit as intrasellulêre boodskappermolekuul optree.

Die vorming van NO kan in sowel cNOS as iNOS onderdruk word deur kompeterende inhibering, met guanidiengesubstitueerde analoè van $L$-arginien, by voorbeeld $\mathbf{N}^{\mathrm{a}}$-monometielarginien (L-NMMA) en $\mathrm{N}^{\mathrm{G}}$-nitro-L-arginienmetielester (L-NAME), wat kompeteer vir die aktiewe setel van die ensiem. Inhibisie van stikstofoksiedsintese kan derhalwe opgehef word deur toevoeging van meer Larginien. ${ }^{21-23}$

Stikstofoksied is ' $n$ vrye radikaal (besit 'n ongepaarde elektron) en is daarom hoogs reaktief. Dit het 'n halfleeftyd van 2 tot 30 sekondes $^{17}$ en reageer maklik met ander vrye radikale. ${ }^{24}$ Dit disintegreer baie vinnig en vorm nitriet en nitraat, reaksies wat deur metale, byvoorbeeld yster, gekataliseer word. So by voorbeeld inaktiveer hemoglobien dit baie vinnig en word dit dan as $\mathrm{NO}_{3}{ }_{3}^{-}$in die urien uitgeskei. ${ }^{16}$ Stikstofoksiedsintetase het 'n heemkomponent en negatiewe terugvoer van stikstofoksiedproduksie kan moontlik ook voorkom: $:^{19}$

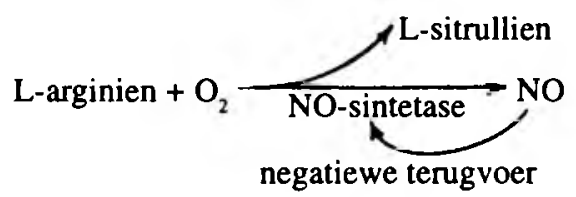

Stikstofoksied is 'n klein, lipofiliese molekuul wat vinnig deur selmembrane diffundeer en saam met sy kort halflewe en hoè reaktiwiteit vorm dit 'n ideale lokale inter- en intrasellulêre boodskappermolekuul. Die intrasellulêre teiken vir NO in meeste weefsels is blykbaar oplosbare heembevattende guanilaatsiklase-ensieme wat die omvorming van guanisientrifosfaat (GTP) na sikliese guanisienmonofosfaat (cGMP) kataliseer (NO aktiveer gualinilaatsiklase deur met die heemkomponent van die ensiem te reageer):

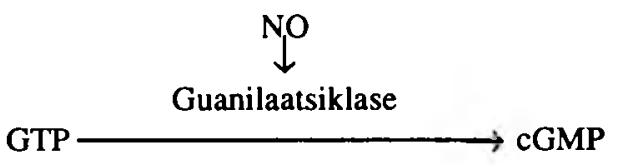

'n Toename in die cGMP-konsentrasie veroorsaak veranderinge in selfunksie, dikwels deur die intrasellulêre kalsiumkonsentrasie te affekteer. Baie hoë konsentrasies van NO kan egter skadelik wees, onder andere deurdat dit ensieme wat oorgangsmetale bevat, insluitende sommige mitochondriale ensieme, inaktiveer. ${ }^{9.19}$

\section{STIKSTOFOKSIED IN DIE PERIFERE SENUWEE- STELSEL}

In die vroeë tagtigerjare is ontdek dat aktiewe vasodilatasie afhanklik is van 'n stof wat deur vaskulêre endoteel vrygestel word. ${ }^{25}$ In 1987 is aangetoon dat die sogenaamde "endothelial derived relaxant factor (EDRF)" stikstofoksied is. Wanneer ' $n$ boodskappermolekuul soos asetielcholien (Ach), wat deur senuwee-eindes vrygestel kan word, aan 'n Achreseptor in die endoteelselmembraan bind, lei dit tot die invloei van $\mathrm{Ca}^{2+}$ in die sel in. Die $\mathrm{Ca}^{2+}$ bind aan kalmodulien en cNOS wat die sintese van NO kataliseer, word geaktiveer. Die NO diffundeer in aangrensende gladdespierselle in waar dit guanilaatsiklase aktiveer om cGMP te vorm en deur 'n kaskade van proteïenkinases word spierverslapping geinisieer. $^{17}$

Stikstofoksied as neuro-oordragstof by nie-adrenergiese, nie-cholinergiese senuwee-eindes

Die geskiedenis van ' $n$ verband tussen NO en die senuweestelsel strek oor slegs 'n paar jaar. Die eerste bewyse dat NO as 'n sinaptiese neuro-oordragstof optree, is in 1988 gerapporteer deur Garthwaite en sy medewerkers. ${ }^{26}$ Dat NO as ' $n$ neuro-oordragstof by sinapse in sowel die sentrale as perifere senuweestelsel funksioneer, is sedertdien deur baie navorsers aangetoon. (Vir uitgebreide oorsigte, raadpleeg Moncada, Palmer \& Higgs $^{7}$ en Sanders \& Ward, ${ }^{13}$ asook Schuman \& Madison. ${ }^{27}$ ) In teenstelling met ander, bekende neuro-oordragstowwe is NO 'n gasmolekuul en hoogs membraandeurlatend. Dit funksioneer dus onafhanklik van die konvensionele seinoordragroete van interaksie met postsinaptiese membraanreseptore, en bereik sy intrasellulêre teiken deur diffusie. Waar meeste oordragstowwe in presinaptiese senuwee-eindes in vesikels gestoor en deur ' $n$ $\mathrm{Ca}^{2+}$-afhanklike proses van eksositose vrygestel word, word NO net op aanvraag gevorm en verlaat dit die sel eenvoudig deur diffusie. Depolarisasie van die presinaptiese membraan veroorsaak verhoogde invloei van $\mathrm{Ca}^{2+}$ waardeur cNOS geaktiveer word, met gevolglike vorming van NO. In die perifere outonome senuweestelsel is NO blykbaar ' $n$ oordragstof by sogenaamde nie-adrenergiese, nie-cholinergiese (NANC) senuwee-eindes vir gladdespierverslapping. ${ }^{1,21,28-30}$

Stikstofoksied aktiveer guanilaatsiklase in die gladdespierselle en die cGMP wat gevolglik gevorm word, aktiveer cGMP-kinases. Verskeie meganismes waardeur cGMPkinases verslapping van vaskulêre gladdespier kan veroorsaak, is voorgestel. Een moontlike meganisme is deur verlaging van die vrye intrasellulêre $\mathrm{Ca}^{2+}$-vlakke, ${ }^{31.32}$ aangesien die aktiwiteit van miosien-ligtekettingkinase, wat kontraksie inisieer, van die intrasellulêre $\mathrm{Ca}^{2+}$-konsentrasie afhanklik is.

Immunohistochemiese tegnieke is ontwikkel waardeur die aanwesigheid van NOS-ensieme in selpopulasies vasgestel kan word ${ }^{33.34}$ en NOS-bevattende senuwee-eindes is aangetoon in die omgewing van die gladdespier van die bronchiale boom, die urinêre stelsel, die dermkanaal en die vaskulêre bed van talle organe en strukture. ${ }^{5.21 .33-37}$ Funksionele abnormaliteite van hierdie senuwees kan bydra tot gewysigde motiliteit of sfinkterfunksie in die verteringstelsel of urienweë, of versteurde reaktiwiteit van die asemhalingsgange of sommige bloedvate. So word infantiele hipertrofiese pilorusstenose en achalasie gekoppel aan belemmering van hierdie senuwees. Verder word ontoereikende vrystelling van NO en gevolglike verlies van vasodilatasie van die corpus cavernosum geassosieer met impotensie. ${ }^{1838-40}$

Chemiese middels soos die nitrovasodilators (bv. gliserieltrinitraat) waarvail die aksie op NO berus, word reeds meer as 'n eeu lank vir koronêre vatspasma in die geneeskunde gebruik. ${ }^{41}$ Die nut van ander stikstofoksiedskenkende middels, en selfs middels wat die produksie van endogene NO kan stimuleer vir die behandeling van byvoorbeeld impotensie, sekere longtoestande en vir die vertraging van kraam, word tans ondersoek. Dit is in sommige toestande wenslik om die sintese of aksie van NO te onderdruk, byvoorbeeld in sommige gevalle van hipotensie. Hier word die gebruik van stowwe soos $\mathrm{N}^{\mathrm{G}}$-monometiel-Larginien (kyk vroeër) ondersoek. 


\section{STIKSTOFOKSIED IN DIE SENTRALE SENUWEE- STELSEL}

In die sentrale senuweestelsel (SSS) is die sintese van NO eerste in die serebellum aangetoon, toe gedemonstreer is dat granulêre selle NO vrystel met stimulering van hulle $\mathrm{N}$ metiel-D-aspartaat-(NMDA-) glutamaatreseptore. ${ }^{26}$ In hierdie neurone word cNOS geaktiveer deur die invloei van $\mathrm{Ca}^{2+}$ via NMDA-reseptorafhanklike ioonkanale..$^{33}$ Deur middel van immunohistochemie is NOS in verskeie spesifieke gebiede in die brein aangetoon..$^{16,33}$ Die NOS-bevattende neurone kleur met die kleurstof nitroblou-tetrazolium in die aanwesigheid van NADPH en word daarom ook soms NADPH-diaforaseneurone genoem..$^{34,42,44}$

\section{Stikstofoksied en NMDA-glutamaatreseptore}

Dat neuronale NO-produksie geïnisieer word deur die stimulering van hulle NMDA-reseptore is van besondere belang weens die rol wat hierdie reseptortipe speel in neuronale plastisiteit, ${ }^{45-8}$ insluitende langtermynpotensiasie (LTP). LTP is waarskynlik betrokke by die leervermoè en geheue, by verlenging en vertakking van senuweeuitgroeisels (vesels), sinapsvorming en sinaptiese oordrag. Aan die ander kant word oormatige aktivering van NMDAreseptore geassosieer met 'n verskeidenheid van akute neurologiese defekte en chroniese neurodegeneratiewe siektes, ${ }^{35.49-51}$ insluitende Parkinsonsiekte, Huntingtonsiekte, amiotrofiese laterale sklerose en die demensie van verworwe immuniteitsgebreksindroom (VIGS).

Wanneer glutamaat met NMDA-reseptore reageer, open die kalsiumkanale wat deur hierdie reseptore beheer word, en die $\mathrm{Ca}^{2+}$ wat gevolglik invloei, bind met kalmodulien wat cNOS aktiveer. Stikstofoksied word geproduseer ${ }^{13.17}$ en dit kan gedeeltelik uitdiffundeer na naasliggende strukture, te wete die presinaptiese senuwee-eindes en astrosietprosesse (wat meeste sentrale sinapse omvou) waar dit guanilaatsiklase aktiveer met gevolglike produksie van cGMP. Dit is moontlik dat NO ook guanilaatsiklase in die selle waar dit geproduseer word, kan aktiveer, maar omdat die $\mathrm{Ca}^{2+}$-vlakke wat nodig is om cNOS te aktiveer, oplosbare guanilaatsiklase inhibeer, ${ }^{32}$ is dié effek hier onwaarskynlik.

\section{Stikstofoksied en neuronale plastisiteit}

Plastisiteit dui op langtermyn fisiologiese en biochemiese veranderinge in sinaptiese en neuronale funksie, en kan selfs strukturele veranderinge insluit. Funksies soos die leervermoë en geheue berus op die plastisiteit van die brein. NMDAreseptore onderlê minstens 'n paar aspekte van plastisiteit. Een daarvan is om langdurige verandering in sinaptiese doeltreffendheid, wat aan die basis van 'n vorm van leervermoë en geheue lê, te inisieer. ${ }^{13.53}$ Nog een betrek die aktiwiteit-afhanklike organisasie van afferente vesels met betrekking tot hulle teikenneurone tydens ontwikkeling. ${ }^{\text {st }}$ Albei hierdie prosesse vereis langdurige aktiwiteit of sogenaamde langtermynpotensiasie. 'n Derde aspek sluit gliaselle in - daar is aanduidings dat astrosiete betrokke kan wees in die ontwikkelingsplastisiteit van sinaptiese verbindings, ${ }^{13.55}$ en NO kan byvoorbeeld proliferasie van gliaselle stimuleer. Astrosiete bevat sowel cNOS as iNOS.

Langtermynpotensiasie (LTP) is waargeneem in baie breinareas en is veral in die hippokampus bestudeer, en wel in die skakeling tussen die CA 1-piramiedeselle en CA3-selle. Vroeër is baie aandag gegee aan moontlike langdurige reaksies in die postsinaptiese sel self wat verantwoordelik kan wees vir LTP, insluitende aanhoudende depolarisasie ${ }^{36}$ en $\mathrm{Ca}^{2+}$-invloei. ${ }^{57.58} \mathrm{Die}$ toename in $\mathrm{Ca}^{2+}$ sou dan een of ander, of ' $n$ kombinasie van postsinaptiese ensieme aktiveer, byvoorbeeld proteïenkinase $\mathrm{C}_{,}{ }^{, 9} \mathrm{Ca}^{2+} / \mathrm{kalmodulienafhanklike}$ proteienkinase $^{60}$ en NOS. ${ }^{61-63}$

Daar is nou egter sterk aanduidings dat ' $n$ retrograde sein vanaf die postsinaptiese sel na die presinaptiese sel herhaalde vrystelling van oordraerstof stimuleer, met gevolglike heraktivering van die postsinaptiese sel. Aangesien NO vrylik diffundeer, is die moontlikheid dat dit 'n retrograde boodskapper in LTP in die hippokampus kan wees deur baie navorsers ondersoek, en lyk dit na 'n baie waarskynlike kandidaat. ${ }^{61-65}$

Langtermyndepressie (LTD) is 'n ander proses wat by plastisiteit betrokke is. Dit is veral in die klimmende vesels (aksone van selle in die inferior olyfkem) en Purkinje-selle van die serebellum, bestudeer. Stimulering van klimmende vesels, wat gebruik maak van NMDA-reseptore, lei tot vrystelling van NO en NOS-inhibeerders blokkeer LTD. ${ }^{68.67}$

Stikstofoksied en vrystelling van neuro-oordragstowwe In verskeie breinareas is aangetoon dat NO sinaptiese funksie moduleer deur die vrystelling van neuro-oordragstowwe uit die presinaptiese eindes te affekteer. Die rustende vrystelling van asetielcholien (Ach) in die basale voorbrein, 'n gebied waar sowel NOS as cholienasetieltransferase aanwesig is, ${ }^{68}$ het onder eksperimentele kondisies verdubbel met toevoeging van NO. ${ }^{69}$ In hippokampuspreparate verhoog toevoeging van 'n NO-skenker vrystelling van sowel Ach as noradrenalien. ${ }^{70}$ Blykbaar oefen NO ook 'n stimulerende effek op die basale dopamienvrystelling deur selle van die corpus striatum uit. ${ }^{71,72}$

Dit is nie bekend wat die molekulêre meganismes is waardeur NO die vrystelling van neuro-oordragstowwe moduleer nie. Aangesien NO Ca ${ }^{2+}$-invloei kan moduleer, ${ }^{73}$ is dit moontlik dat modulering van vrystelling langs die weg deur NO bewerkstellig word. ' $n$ Ander moontlikheid is om die funksie van vesikelproteiene te wysig. ${ }^{27}$

\section{Stikstofoksied en neuro-endokriene funksies}

Daar bestaan verskeie indirekte aanduidings dat NO betrokke is in neuro-endokriene funksies, en meer spesifiek by die hipotalamus-hipofise-as. Die posterior lob van die hipofise kleur byvoorbeeld positief vir NOS, asook die selliggame van die supraoptiese en paraventrikulêre hipotalamuskeme wat na die posterior hipofise projekteer. ${ }^{33.68}$ Blykbaar is NMDA-reseptore betrokke by die hipotalamus-hipofisestelsel, en dit is voorgestel dat NMDA-bemiddelde aksies in die neuro-endokriene-as, NO betrek. ${ }^{27}$

\section{Stikstofoksied, neurotoksisiteit/-degenerasie en neuro- beskerming}

Dat oormaat eksiterende aminosuurneuro-oordragstowwe, veral glutamaat, die afsterf van reseptiewe neurone kan veroorsaak, word reeds algemeen aanvaar. ${ }^{47}$ Hulle word selfs eksitotoksiese stowwe genoem. Hulle toksisiteit word met NMDA-reseptore geassosieer. Oormaat stikstofoksied word lank reeds aan neuronale degenerasie en seldood gekoppel, maar die rol van NO in neurotoksisiteit is nog onduidelik en die literatuur daaroor is vol teenstrydighede. ${ }^{24.74}$ Dit lyk ook asof spesifieke neurone wat positief vir diaforase kleur (en dus waarskynlik NOS bevat), besonder weerstandbiedend teen neurale skade kan wees. ${ }^{75-78}$ Aansluitend hierby is daar verder eksperimentele aanduidings dat NO NMDAbemiddelde seldood $k$ an voorkom. ${ }^{75}$ 
In teenstelling met bovermelde data is heelwat resultate gepubliseer wat daarop dui dat NO glutamaatbemiddelde seldood bevorder, of noodsaaklik is daarvoor. ${ }^{14,48,79-81}$ Verskeie neurodegeneratiewe siektes, insluitende Alzheimer- en Huntington-siekte ${ }^{47,82}$. VIGS-demensie ${ }^{81}$ en neuronale beskadiging weens serebrale infarksie ${ }^{48.81,82}$ word met 'n oormatige produksie van NO geassosieer. Verskeie meganismes vir NOtoksisiteit is voorgestel, insluitende inhibisie van mitochondriale ensieme soos cis-akonitase, onderdrukking van die mitochondriale elektron-transportketting, inhibisie van ribonukleotiedreduktase, DNA-beskadiging, monoadenosiendifosfaat-(ADP-)ribosilering en S-nitrosilering van gliseraldehied-3-fosfaatdehidrogenase. ${ }^{14,48,81}$ Laastens kan NO met superoksiedanione $\left(\mathrm{O}_{2}{ }^{\circ}\right)$ reageer om peroksinitrietanione ( $\left.\mathrm{ONOO}^{-}\right)$te vorm. Hierdie anione kan ontbind om uiters skadelike hidroksielradikale en $\mathrm{NO}_{2}$ te vorm.

\section{Stikstofoksied en pyn}

Daar is besliste aanduidings dat NMDA-glutamaatreseptoraktivering ' $n$ rol speel in die meganisme wat betrokke is by hiperalgesie en spontane pyn as gevolg van weefselselbeskadiging. ${ }^{22.83} \mathrm{Na}$ weefselbeskadiging word 'n ligte, skadelose prikkel dikwels as pynlik ervaar. Hiermee saam gaan 'n verhoogde sensitiwiteit van die pynreseptore in die beseerde gebied, met gevolglike vermeerderde impulsopwekking. Hierdie verhoogde nosiseptiewe aktiwiteit kan neuronale plastisiteit in die spinale posteriorhoringselle wat invoer vanaf die pynreseptore ontvang, inisieer ${ }^{22}$ Dié proses van nosiseptiewe prosessering sluit die neuropeptied- en eksiterende aminosuuroordragstowwe in. Glutamaatimmunoreaktiewe senuwee-eindes is inderdaad in die substantia gelatinosa aangetoon ${ }^{84}$ en dit lyk dus moontlik dat NMDAreseptore in pynimpulsoordrag in die rugmurg betrokke kan wees. ${ }^{83}$ 'n LTP-meganisme kan moontlik bydra tot die veranderinge in pynervaring.

\section{SuMMARY}

Nitric oxide (NO), a poisonous gas molecule, was recently identified as a cellular messenger in biological systems. In the human body NO is formed and released by several different types of cells in various organs. It apparently plays a role as signalling molecule in fundamental functions of nearly all the body systems. Nitric oxide seems to be principally involved firstly, in the cardiovascular system, where it mediates vasodilation, secondly, in the defence systems, where it mediates macrophage cytotoxic activity against micro-organisms, and thirdly in the nervous system. This review provides only a short summary of the current knowledge of its functions as a neural messenger in the nervous system.

In the nervous system nitric oxide is not synthesised in advance and stored in vesicles like the "classic" neurotransmitters; it is not released through exocytosis and does not react with postsynaptic membrane receptors. Nitric oxide is synthesised from the amino acid L-arginine by several isoforms of nitric oxide synthase (NOS) enzymes. The neuronal NOS is calcium dependent and normally only produces small amounts of NO. Nitric oxide diffuses rapidly through cell membranes and its receptor is located intracellularly. It has a half-life of only a few seconds and is inactivated by the haem moiety of haemoglobin. The intracellular target for NO is a soluble guanylate cyclase enzyme which catalyses the formation of cyclic guanosine monophosphate (cGMP). The cGMP can mediate changes in normal cellular processes.
In the peripheral nervous system NO acts as a neurotransmitter at nonadrenergic, noncholinergic (NANC) autonomic nerve terminals. It mediates relaxation of smooth muscle fibres in several organs and the vascular system.

The principal role of NO in the central nervous system (CNS) seems to be as a neuromodulatory substance, analogous to some neurotransmitters. Neuromodulation underlies neural plasticity. One example of a modulatory function of NO is associated with N-methyl-D-aspartate (NMDA) glutamate receptor activity, which in tum is presumably involved in learning and memory processes on a cellular level. These processes include long-term potentiation (LTP). There are also indications that NO may play a role in the central processing of pain information. Nitric oxide may furthermore affect the release of other neurotransmitters in the CNS (eg acetylcholine), and it may influence neuro-endocrine functions.

When large amounts of NO are formed in response to excessive NMDA receptor activity caused by the excitatory amino acid transmitter glutamate, NO may mediate neuronal damage. NMDA toxicity acting via NO may account for some neurodegeneration associated with Parkinson's disease, for example amyotrophic lateral sclerosis and the degeneration due to AIDS, trauma and cerebral ischaemia. Several mechanisms for NO neurotoxicity have been suggested, including inhibition of mitochondrial enzymes and the electron transport chain, DNA damage and the reaction of NO with superoxide to form peroxide nitrite anion, which is a powerful oxidant, capable of damaging all major components of a cell.

\section{LITERATUURVERWYSINGS}

1. Palmer, R.M.J., Ferridge, A.G. \& Moncada, S. (1987). Nitric axide release accounts for the biological activity of endothelium-derived relaxing factor, Nature, 327, 524-526.

2. Palmer, R.M.J., Rees, D.D., Ashton, D.S. \& Moncada, S. (1988). $\mathrm{L}$-arginine is the physiological precurser for the formation of nitric oxide in endothelium dependent relaxation, Biochem. Biophys. Res. Comm., 153, 1251-1256.

3. Marletta, M.A., Yoon, P.S., Iyenger, R., Leat, C.D. \& Wishnok, J.S. (1988). Macrophage oxidation of 1 -arginine to nitrite and nitrate : nitric oxide is an intermediate, Biochemistry, 21, 8706-8711.

4. Hibbs, J.B., Taintor, R.R., Vavrin, Z. \& Rachlin, E.M. (1989). Nitric oxide: a cytotoxic activated macrophage effector molecule, Biochem. Biophys. Res. Comm., 157, 87-94.

5. Culotta, E. \& Koshland, D.E. (1992). NO news is good news, Science, 258, 1862-1865.

6. Koshland, D.E. (1992). The molecule of the year, Science, 258, 1861.

7. Moncada, S., Palmer, R.M.J. \& Higgs, E.A. (1991). Nitric oxide: physiology, pathophysiology and pharmacology, Pharmacol. Rev., 43, $109-142$.

8. Luscher, T.F. (1992). Endogenous and exogenous nitrates and their role in myocardial ischaemia, Br. J. Clin. Pharmacol., 34, 295-355.

9. Hibbs, J.B. (1991). Synthesis of nitric oxide from L-arginine: a recently discovered pathway induced by cytokines with antitumour and antimicrobial activities, Res. Immunol., 142, 565-569.

10. Green, S.J., Neltzer, M.S., Hibbs, J.B. Jr \& Nancy, C.A. (1990). Activated macrophages destroy intracellular Leischmania major amastigotes by an L-arginine-dependent killing mechanism, $J$. Immunol., 144, 278-283.

11. Nathan, C. \& Hibbs, J.B. (1991). Role of nitric oxide synthesis in antimicrobial activity. Curr. Opin. Immunol., 3, 65-70.

12. Lin, J.Y. \& Chadec, K. (1993). Macrophages cytotoxicity against Entamoeba histolytica throphozoites is mediated by nitric oxide from L-arginine, J. Immunol., 148, 3999-4005.

13. Garthwaite, J. (1991). Glutamate, nitric oxide and cell-cell signalling in the nervous system, Trends Neurasci., 14, 60-67.

14. Dawson, T.M., Dawson, V.L. \& Snyder, S.H. (1992). A novel neuronal messenger molecule in brain: The free radical, nitric oxide, 
Annals Neurophysiol., 32, 297-311

15. Sanders, K.M. \& Ward, S.M. (1992). Nitric oxide as a mediator of non-adrenergic and non-cholinergic transmission, Am. J. Physiol., 262 (Gastrointest Liver Physiol 25), G 379-392.

16. Anggárd, E. (1994). Nitric oxide: mediator, murderer and medicine, The Lancet, 343, 1199-1205.

17. Lowenstein, C.J., Dinerman, J.L. \& Snyder, S.H. (1994). Nitric oxide: A physiologic messenger, Ann. Intern. Med., 20, 227-237.

18. Marsden, P.A., Heng, H.H.Q., Scherer, S.W., Stewart, R.J., Hall, A.V. \& Shr, X-M. (1993). Structure and chromosomal localization of the human constitutive endothelial nitric oxide synthase gene, $J$. Biol. Chem., 268, 17478-17488.

19. Vallance, P. \& Collier, J. (1994). Biology and clinical relevance of nitric oxide, B.M.J., 309, 453-457.

20. Xie, Q.W., Cho, H.J., Calayccry, J., Mumford, R.A., Swiderek, K.M \& Les, T.D. (1992). Cloning and characterization of inducible nitric oxide synthase from mouse macrophages, Science, 256, 225-228.

21. Sneddon, P. \& Graham, A. (1991). Role of nitric oxide in the autonomic innervation of smooth muscle, J. Auton. Pharmacol., 11,445456.

22. Dubner, R. \& Ruda, M.A. (1992). Activity-dependent neuronal plasticity following tissue injury and inflammation, Trends Neurol. Sci., 15, 96-103.

23. Petros, A., Bennett, D. \& Vallance, P. (1991). Effect of nitric oxide synthase inhibitors on hypotension in patients with septic shock, Lancet, 338, 1557-1558.

24. Beckman, J.S. \& Crow, J.P. (1993). Pathological implications of nitricoxide, superoxide and peroxynitrite formation, Biochem. Soc. Trans., 21, 330-334.

25. Furchgott, R.F. Z Zawadzki, J.V. (1980). The obligatory role of endothelial cells in the relaxation of arterial smooth muscle by acetylcholine, Nature, 288, 373-376.

26. Garthwaite, J., Charles, S.L. \& Chess-Williams, R. (1988). Endothelium-derived relaxing factor release on activation of NMDA receptors suggests role as intracellular messenger in the brain, $\mathrm{Na}$ ture, 336, 385-388.

27. Schuman, E.M. \& Madison, D.V. (1994). Nitric oxide and synaptic function, Annu. Rev. Neurosci., 17, 153-183.

28. Bell, C. (1991). Novel peripheral neurotransmitters. In: International Encyclopedia of Pharmacology and Therapeutics, Vol 135, bls 5-8. Ed C Bell. Pergamon Press, Oxford.

29. Ward, S.M., McKeen, E.S. \& Saunders, K.M. (1992). Role of nitric oxide in nonadrenergic, noncholinergic inhibitory junction potentials in canine ileocolonic sphincter, Br. J. Pharmacol, 105, 776-782.

30. Ignarro, L.J. (1990). Nitric oxide: A novel signal transduction mechanism for transcellular communication, Hypotension, 16, 477-483.

31. Lincoln, T.M. \& Cornwell, T.L. (1993). Intracellular GMP receptor proteins, FASEB J., 7, 328-338.

32. Ignarro, L.J. (1990). Biosynthesis and metabolism of endotheliumderived nitric oxide, Annu. Rev. Pharmacol. Toxicol., 30, 535-560.

33. Bredt, D.S., Hwang, P.M. \& Snyder, S.H. (1990). Localisation of nitric oxide synthase indicating a neural role for nitric oxide, $\mathrm{Na}$. ture, 347, 768-770.

34. Bredt, D.S., Glatt, C.E., Hwang, P.M., Fotuchi, M., Dawson, T.M. \& Snyder, S.H. (1991). Nitric oxide synthase protein and mRNA are discretely localized in neuronal populations of mammalian CNS together with NADPH diaphorages, Neuron, 7, 61 5-624.

35. Gibaldi, M. (1993). What is nitric oxide and why are so many people studying it? J. Clin. Pharmacol., 33, 488-496.

36. Bredt, D.S. \& Snyder, S.H. (1992). Nitric oxide: A novel neuronal messenger, Neuron, 8, 8-11.

37. Snyder, S.H. \& Bredt, D.S. (1992). Biological roles of nitric oxide, Scientific American, May 1992, 28-35.

38. Moncada, S. \& Higgs, A. (1993). Mechanism of disease: the Larginine-nitric oxide pathway, N. Engl. J. Med., 329, 2002-2012.

39. Calver, A., Collier, J. \& Vallance, P. (1993). Nitric oxide and cardiovascular control, Exp. Physiol., 78, 303-326.

40. Burnett, A., Loewenstein, C.J., Bredt, D.S., Chang. T.S.K. \& Snyder, S.H. (1992). Nitric oxide: a physiologic mediator of penile erection, Science, 257, 401-403.

41. Feelish, M. (1991). The biochemical pathways of nitric oxide formation from nitrovasodilators: appropriate choice of exogenous NO donors and aspects of preparation and handling of aqueous NO solutions, J. Cardiovasc. Pharmacol., 17 (suppl 3), S25-33.

42. Young, H.M., Furness, J.B., Shuttleworth, C.W., Bredt, D.S. \&
Snyder, S.H. (1992). Co-localization of nitric oxide synthase immunoreactivity of nitric oxide synthase immunoreactivity and NADPH diaphorase staining in neurons of the guinea-pig intestine Histochemistry, 97, 375-378.

43. Hope, B.T., Michael, G.J., Knigge, K.M. \& Vincent, S.R. (1991). Neuronal NADPH diaphorase is a nitric oxide synthase. Proc. Natl. Acad. Sci. USA., 88, 2811-2814.

44. Bredt, D.S., Glatt, C.E., Hwang, P.M., Fotuhi, M., Dawson, T.M. \& Snyder, S.H. (1991). Nitric oxide synthase protein and mRNA are discretely localized in neuronal populations of mammalian central nervous system together with NADPH diaphorase, Neuron, 7, 615-624.

45. Zorumski, C.F. \& Izumi, Y. (1993). Nitric oxide and hippocampal synaptic plasticity, Biochem. Pharmacol., 46, 777-785.

46. Dubner, R. \& Ruda, M.A. (1992). Activity-dependent neuronal plasticity following tissue injury and inflammation, Trends Neurosc., 15, 96-103.

47. Hockfelt, T., Zhang, X. \& Wiesenfelt-Hallin, Z. (1994). Messenger plasticity in primary sensory neurons following axotomy and its functional implications, Trends Neurosc., 17(1), 22-30.

48. Hawkins, R.D., Zhuo, M. \& Aranuo, O. (1994). Nitric oxide and carbon monoxide as possible retrograde messengers in hippocampal long-term potentiation, J. Neurobiol., 25(6), 652-665

49. Lipton, S.A. \& Rosenberg, P.A. (1994). Excitatory amino acids as a final common pathway for neurologic disorders, $N$. Engl. J. Med., 330, 613-622.

50. Meldrum, B. \& Garthwaite, J. (1990). Excitatory amino acid neurotoxicity and neurodegenerative disease, Trends Pharmacol. Sci. 11, 379-387.

51. Dawson, T.M., Zhang, J., Dawson, V.L. \& Snyder, S.H. (1994). Nitric oxide: cellular regulation and neuronal injury, Prog. Brain Res., 103, 365-369.

52. Knowles, R.G., Palacois, M., Palmer, R.M.J. \& Moncada, S. (1989) Formation of nitric oxide from $L$-arginine in the central nervous system: a transduction mechanism for stimulation of soluble guanylate cyclase, Proc. Nall. Acad. Sci. USA, 89, 5159-5162.

53. Shuman, E.M. (1994). Molecular consequences of diffusable signalling: locally distributed synaptic enhancement in hippocampal neurones, Semin. Cell Biol., 5(4), 251-261.

54. Collingridge, G.L., Kehl, S.J. \& McLennan, H. (1983). Excitatory amino acids in synaptic transmission in the Schaffer collateral-commisural pathway of the rat hippocampus, J. Physiol., 334, 33-46.

55. Murphy, S., Simmons, L.A., Garcia, A., Feinstein, E.G., Reis, D.J., Minc-Golomb, D. \& Schwartz, P. (1993). Synthesis of nitric oxide in CNS glial cells, Trends Neurosci., 8, 323-328.

56. Malinow, R. \& Miller, J.P. (1986). Postsynaptic hyperpolirization during conditioning reversibly blocks induction of long-term potentiation, Nature, 320, 529-530.

57. Lynch G., Larson, J. \& Kelso, S. (1983). Intracellular injections of EGTA block induction of hippocampal long-term potentiation, $\mathrm{Na}$ ture, 305, 719-721.

58. Malenka, R.C., Kauer, J.A., Zuker, R.J. \& Nicoll, R.A. (1988). Postsynaptic calcium is sufficient for potentiation of hippocampal synaptic transmission, Science, 242, 81-84

59. Malinow, R., Madison, D.V. \& Tsien, R.W. (1988). Persistent protein kinase activity underlies long-term potentiation, Narure, 335, 820-824.

60. Silva, A.J., Stevens, C.F., Tonegawa, S. \& Wang. Y. (1992). Deficient hippocampal long-term potentiation in _-calcium-calmodulin kinase II mutant mice, Science, 257, 201-206.

61. Bohme, G.A., Bon, C. \& Stutzmann, J.M. (1991). Possible involvement of nitric oxide in long-term potentiation, Eur. J. Pharmacol., 199, 379-381

62. Schuman, E.M. \& Madison, D.V. (1991). A requirement for the intercellular messenger nitric oxide in long-term potentiation, Science, 254, 1503-1506.

63. Haley, J.E., Wilcox, G.L. \& Chapman, P.F. (1992). The role of nitric oxide in long-term potentiation, Neuron, 8, 211-216.

64. Gally, J.A., Matagne, R.R., Recke, G.N. \& Edelman, G.M. (1990). The NO hypothesis: possible effects of a short-lived, rapidly diffusible signal in the development and function of the nervous system, Proc. Natl. Acad. Sci. USA, 87, 3547-3551.

65. O'Dell, T.J., Hawkins, R.D., Kandel, E.R. \& Aracio, O. (1991). Tests of the roles of two diffusible substances in long-term potentiation: evidence for nitric oxide as a possible early retrograde messenger, Proc. Natl. Acad. Sci. USA, 88, 11285-11285.

66. Shibuki, K. \& Okada, D. (1991). Endogenous nitric oxide release 
required for long-term synaptic depression in the cerebellum, $\mathrm{Na}$ ture, 349, 326-328.

67. Daniel, H., Hemart, N., Jaillard, D. \& Crépel, F. (1993). Long-term depression requires nitric oxide and guanosine 3':5' cyclic monophosphate production in Purkinje cells, Eur. J. Neurosci., 5, 1079-1082.

68. Dawson, T.M., Bredt, D.S. \& Fotuhi, M. (1991). Nitric oxide synthase and neuronal NADPH diaphorase are identical in brain and peripheral tissue, Proc. Natl. Acad. Sci. USA, 88, 7791-7801.

69. Prast, H. \& Phillipu, A. (1992). Nitric oxide releases acetylcholine in the basal forebrain, Eur. J. Pharmacol., 216, 139-140.

70. Lonart, G., Wang, J. \& Johnson, K.M. (1992). Nitric oxide induces neurotransmitter release from hippocampal slices, Eur. J. Pharmacol., 220, 271-272.

71. Zhu, X.Z. \& Luo, L.G. (1992). Effect of nitroprusside (nitric oxide) on endogenous dopamine release from rat striatal slices, $J$. Neurochem., 59, 932-935.

72. Hanbauer, I., Wink, D. \& Osawa, Y. (1992). Role of nitric oxide in NMDA-evoked release from [ $\left.{ }^{3} \mathrm{H}\right]$-dopamine striatal slices, Neuroreport, 3, 409-412.

73. Lei, S.Z., Pan, Z-H. \& Aggarwa', S.K. (1992). Effect of nitric oxide production on the redox modulatory site of the NMDA receptor channel complex, Neuron, 8, 1087-1099.

74. Beckman, J.S., Jun Chen, Crow, J.P. \& Yao Zu Ye. (1994). Reactions of nitric oxide, superoxide and peroxynitrate with superoxide dismutase in neurodegeneration, Prog. Brain Res., 103, 371-380.

75. Ferrante, R.J., Kowall, N.W., Beal, M.F. et al. (1985). Selective sparing of a class of striatal neurons in Huntington's disease. Science, 230, 561-563.
76. Uemura, Y., Kowall, N.W. \& Beal, M.F. (1990). Selective sparing of NADPH-diaphorase-somatostatin-neuropeptide $Y$ neurons in ischemic gerbil striatum, Ann. Neurol, 27, 620-625.

77. Koh, J-Y. \& Choi, D.W. (1988). Vulnerability of cultured cortical neurons to damage by excitotoxins: differential susceptibility of neurons containing NADPH-diaphorase, J. Neurosci., 8, 2153-2163.

78. Hyman, B.T., Marzloff, K. \& Wenniger, J.J. (1992). Relative sparing of nitric oxide synthase-containing neurons in the hippocampal formation in Alzheimer's disease, Ann. Neurol., 32, 818-820.

79. Dawson, V.L., Dawson, T.M., London, E.D., et al. (1991). Nitric oxide mediates glutamate neurotoxicity in primary cortical culture, Proc. Natl. Acad. Sci. USA, 88, 6368-6371.

80. Izumi, Y., Clifford, D.B. \& Zorumski, C.F. (1992). Inhibition of long-term potentiation by NMDA-mediated nitric oxide release, Science, 257, 1273-1276.

81. Dawson, T.M. \& Snyder, S.H. (1994). Gases as biological messengers: nitric oxide and carton monoxide in the brain, $J$. Neurosci., 14(9), 5149-5159.

82. Choi, D.W. (1990). Cerebral hypoxia: some new approaches and unanswered questions, J. Neurosci., 10, 2493-2501.

83. Meller, S.T. \& Gebhart, G.F. (1993). Nitric oxide (NO) and nociceptive processing in the spinal cord, Pain, 52, 127-136.

84. Merighi, A., Polak, J.M. \& Theodosis, D.T . (1991). Ultrastructural visualization of glutamate and aspartate immunoreactivities in the rat dorsal horn with special reference to the co-localization of glutamate, substance $P$ and calcitonin-gene related peptide, Neuroscience, $40,67-80$. 